\title{
Sea Lavender (Heliotropium gnaphalodes L.): Identification and Uses ${ }^{1}$
}

\author{
Stephen H. Brown, Marc S. Frank, and Andrew K. Koeser²
}

Family: Boraginaceae (borage family)

Common Names: sea lavender; bay lavender; iodine bush; sea rosemary

Origin: coastal southeastern Florida from Brevard County to the Keys; West Indies; Bermuda; Mexico (Yucatan Peninsula); the Caribbean coast of Central America and Venezuela

USDA Zone: 9B-12B $\left(26^{\circ} \mathrm{F}\right.$ minimum $)$

Plant Type: shrub

Growth Rate: fast when young; slower when mature

Typical Height: 5 feet

Leaf Persistence: evergreen

Leaf Type: simple, entire

Flower Color: white

Fruit Color: brown at maturity

Light Requirements: full sun
Soil Requirements: sandy; free-draining; alkaline to neutral or slightly acidic

Drought Tolerance: high

Salt Tolerance: high

Wind Tolerance: high

Nutritional Requirements: low

Propagation: cuttings; ground-layering; seeds

UF/IFAS Assessment: not assessed (native)

Regulatory Status: endangered in Florida

Human Hazards: none

Occasional Problems: stem and branch dieback; root rot

Uses: coastal and inland plantings; specimen; dune reclamation; massed plantings; foundation plant; uneven groundcover; low, irregular hedge

1. This document is ENH1299, one of a series of the Environmental Horticulture Department, UF/IFAS Extension. Original publication date August 2018. Visit the EDIS website at http://edis.ifas.ufl.edu.

2. Stephen H. Brown, horticulture agent, UF/IFAS Extension Lee County; Marc S. Frank, Extension botanist, UF/IFAS Plant Identification and Information Service, University of Florida Herbarium; and Andrew K. Koeser, assistant professor, UF/IFAS Gulf Coast Research and Education Center; UF/IFAS Extension, Gainesville, FL 32611.

The Institute of Food and Agricultural Sciences (IFAS) is an Equal Opportunity Institution authorized to provide research, educational information and other services only to individuals and institutions that function with non-discrimination with respect to race, creed, color, religion, age, disability, sex, sexual orientation, marital status, national origin, political opinions or affiliations. For more information on obtaining other UF/IFAS Extension publications, contact your county's UF/IFAS Extension office. 
Table 1. Nomenclature of Heliotropium gnaphalodes L.

\begin{tabular}{|l|l|}
\hline Kingdom & Plantae \\
\hline Phylum & Tracheophyta \\
\hline Order & Boraginales \\
\hline Genus & Boraginaceae \\
\hline Species & Heliotropium \\
\hline Synonyms & $\begin{array}{l}\text { Argusia gnaphalodes (L.) Heine; Mallotonia } \\
\text { gnaphalodes (L.) Britton; Tournefortia gnaphalodes (L.) } \\
\text { R. Br. ex Roem. \& Schult. }\end{array}$ \\
\hline
\end{tabular}

\section{Range}

Sea lavender (Heliotropium gnaphalodes L.) is a native plant found naturally along the Atlantic coast of central and south Florida. The area includes Brevard County to Miami-Dade, Monroe (mainland), and Collier counties into the Florida Keys (Monroe County). Sea lavender is on Florida's endangered species list due to development of the coastal areas for houses, businesses, and recreation. Outside the United States, its range extends to Bermuda, the West Indies (the Bahamas and the Greater and Lesser Antilles), Mexico's Yucatan Peninsula, and the Caribbean coast of Central America and Venezuela. It may be cultivated in other warm climates where it does not seem to have naturalized.

\section{Habit}

Sea lavender is an evergreen, mounding-to-sprawling shrub that can grow to be 10 feet tall, although it typically grows shorter. It sometimes forms colonies more than 20 feet wide. Plants are usually as broad, or broader, than they are tall. The lower branches may form adventitious roots when covered by sand. They trap sand and stabilize dunes, thereby facilitating the establishment of other plants. The sprawling habit of some older plants often exposes lower branches and soil within the mound.

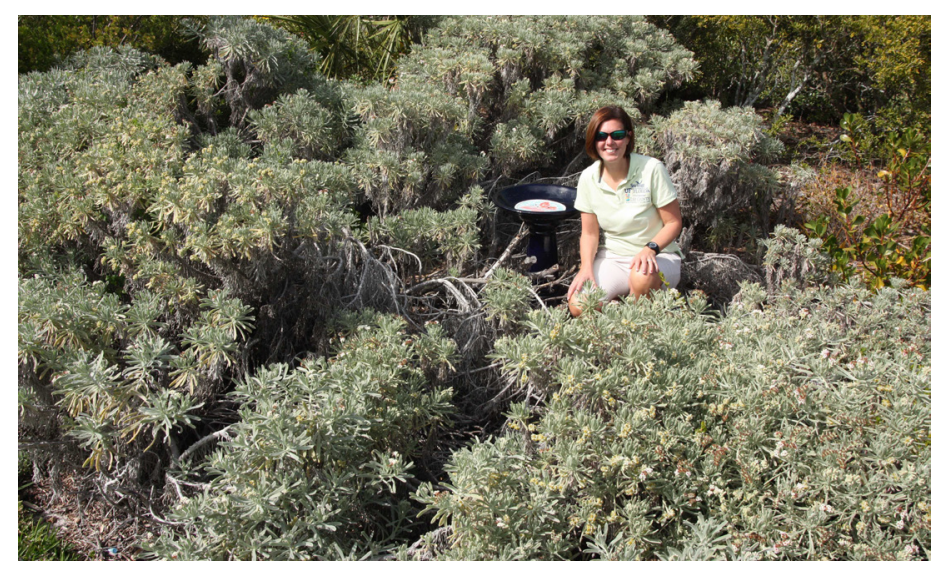

Figure 1. Sea lavender colony cultivated in a landscape showing typical clumping habit with gaps within the clump. Credits: Stephen H. Brown, UF/IFAS

\section{Stems and Leaves}

New stems are covered with soft, light gray hairs. Stems turn yellowish-green and become less hairy with age. Often, many dead, hanging leaves persist on the stems. Lower stems are thicker, woody, and brown or blackish in color. Trunks may grow as thick as 8 inches.

Leaves are alternate and densely arranged in tufts at the ends of stems. Leaf blades are simple, entire, thick, and stalkless. They are typically linear-spatulate to linearobovate, measuring 2 to 5 inches long and up to $1 / 4$ inches wide. Leaves often have a slight upward curve above the middle. The leaf texture is slightly succulent. Both the top and bottom surfaces are densely covered with short, soft, silky, light gray hairs. Plant frequently have dry, dead leaves hanging downward just below the living leaves. When broken, leaves and stems have no discernable odor. Apparently, sea lavender gets its common name from its physical resemblance to lavender and rosemary, not from any closeness in fragrance.

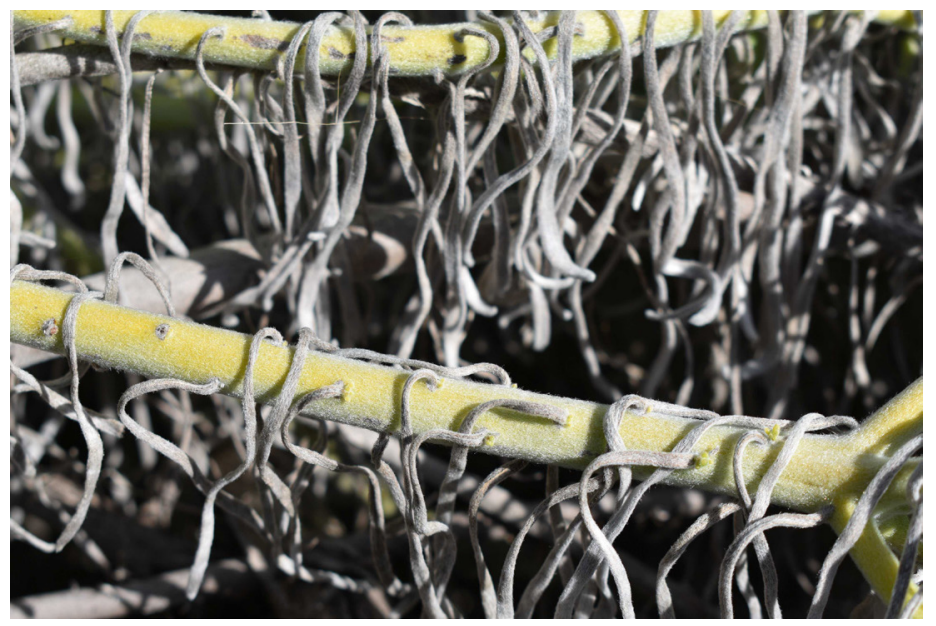

Figure 2. Yellowish-green stems with hanging persistent dead leaves. Credits: Stephen H. Brown, UF/IFAS

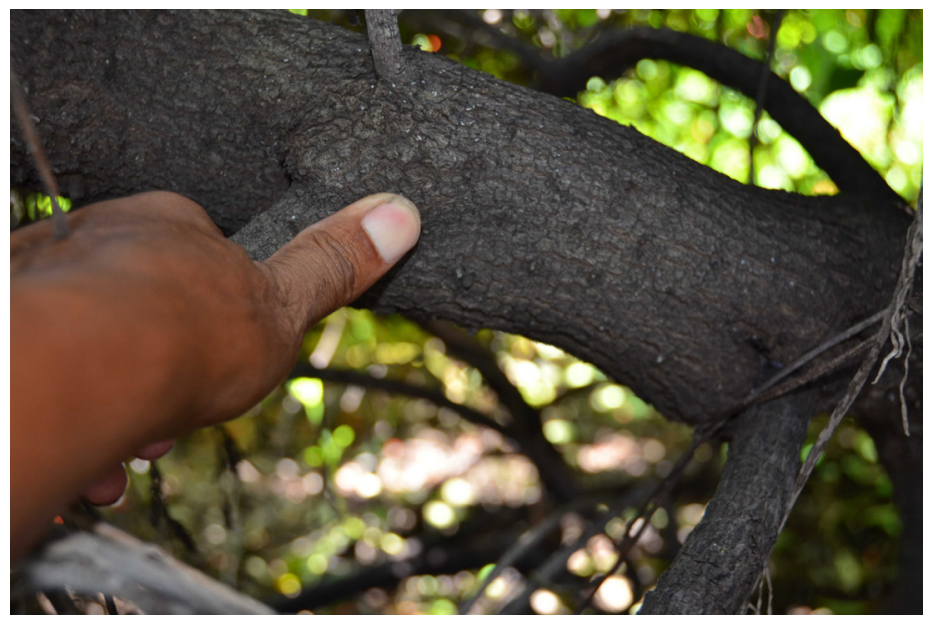

Figure 3. Lower branch of old specimen.

Credits: Stephen H. Brown, UF/IFAS 


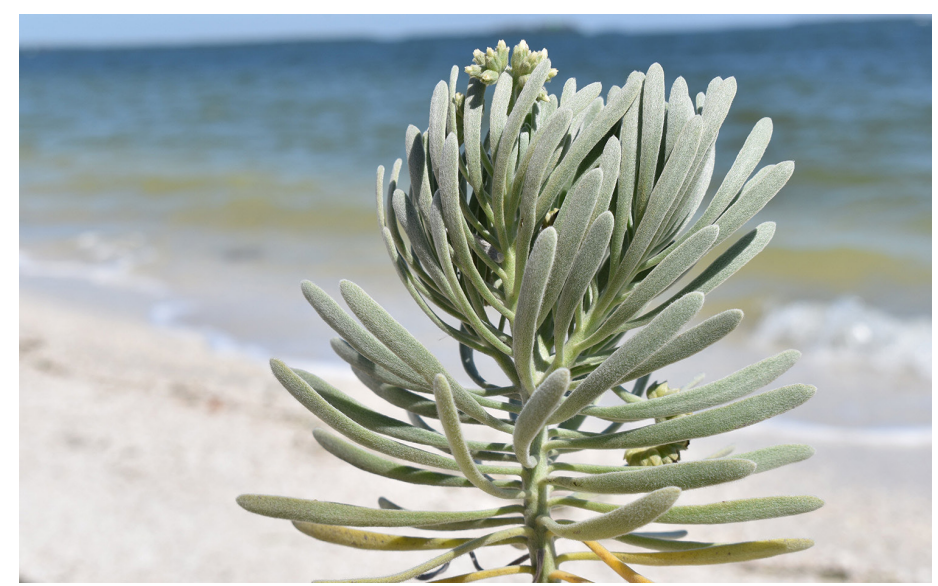

Figure 4. Recognizably alternate and spiral leaves below dense terminal tuft of leaves.

Credits: Stephen H. Brown, UF/IFAS

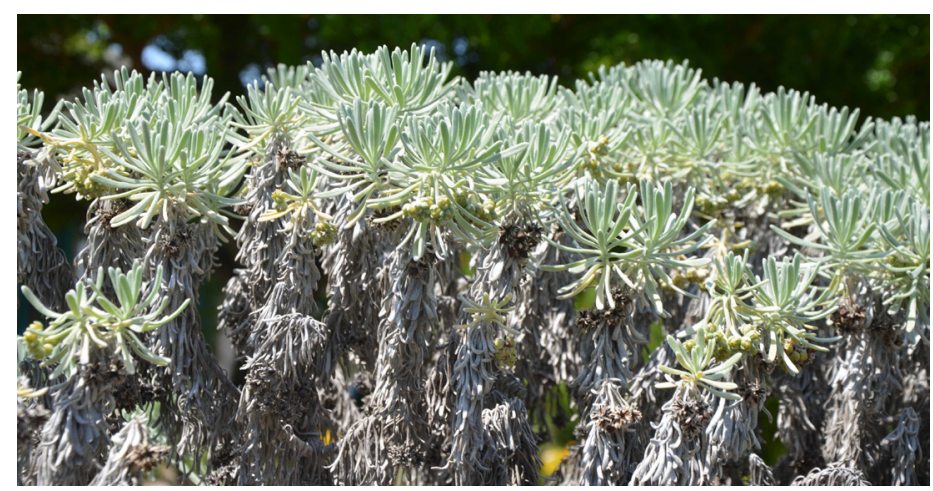

Figure 5. Hanging dead leaves below living leaves.

Credits: Stephen H. Brown, UF/IFAS

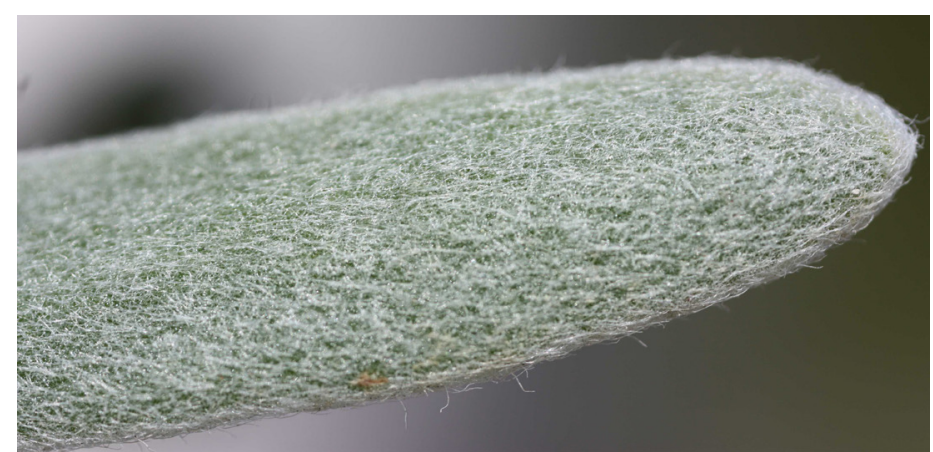

Figure 6. Leaves are densely covered with short, soft, light gray hairs. Credits: Stephen H. Brown, UF/IFAS

\section{Flowers}

Sea lavender may bloom throughout the year, but flowering is most pronounced during fall and winter. The inflorescence is a terminal, helicoid (spirally coiled and one sided), few-branched cyme that extends just beyond the terminal tuft of leaves. The flowers are densely arranged in curved clusters on the helicoid cymes. Both the inflorescence stalk and the calyx are silky gray pubescent, like the leaves. Individual flowers are less than $1 / 4$ inches wide and tall. There are five spreading-to-reflexed white petal lobes. The base of the flower forms a tube with a greenish-yellow to pinkish throat. The flowers have a mild, sweet fragrance.

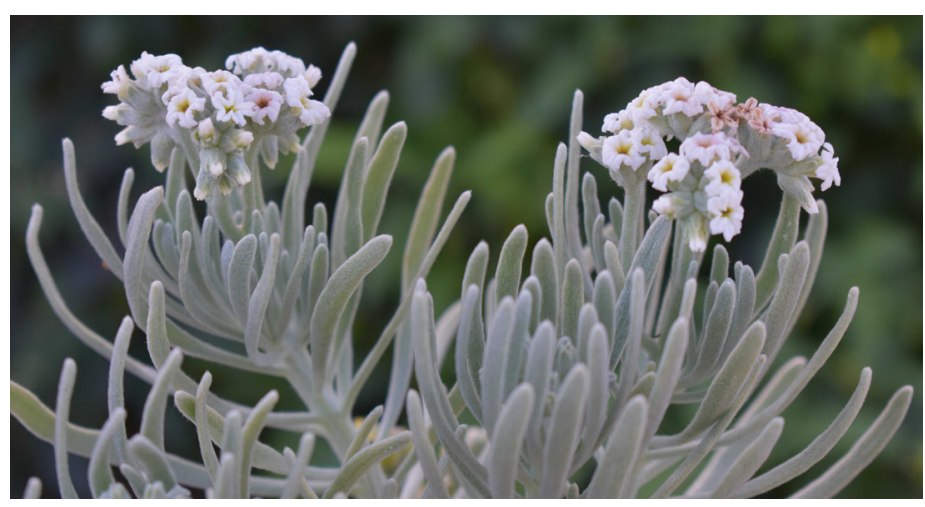

Figure 7. Flowers borne in terminal, spirally coiled, one-sided cymes. Credits: Stephen H. Brown, UF/IFAS

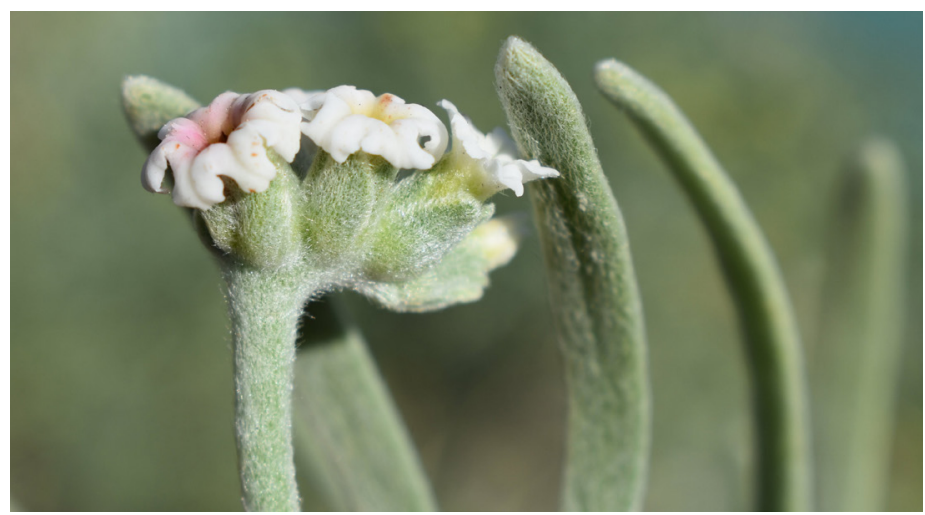

Figure 8. Flowers are stalkless, with five white spreading petals with greenish-yellow to pinkish throats.

Credits: Stephen H. Brown, UF/IFAS

\section{Fruit}

Flowers and fruit are often visible simultaneously. The fruit are about $1 / 4$ inch long, ovoid drupes, with a conical tip and smooth exterior. The interior texture is corky, which facilitates dispersal on ocean currents. Immature fruit are yellowish, with a black persistent style at the top. At maturity, the fruit are brown to black in color and split into two corky or spongy nutlets, each containing two seeds. If not supported by leaves, the fruiting stalks usually hang downward under the collective weight of the fruit.

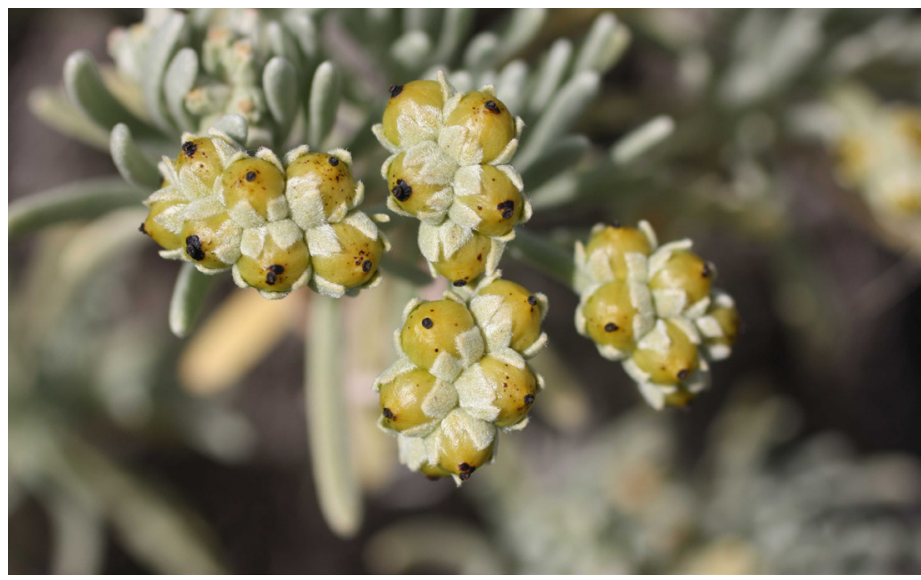

Figure 9. Maturing drupes in small clusters held just above the foliage. Credits: Stephen H. Brown, UF/IFAS 


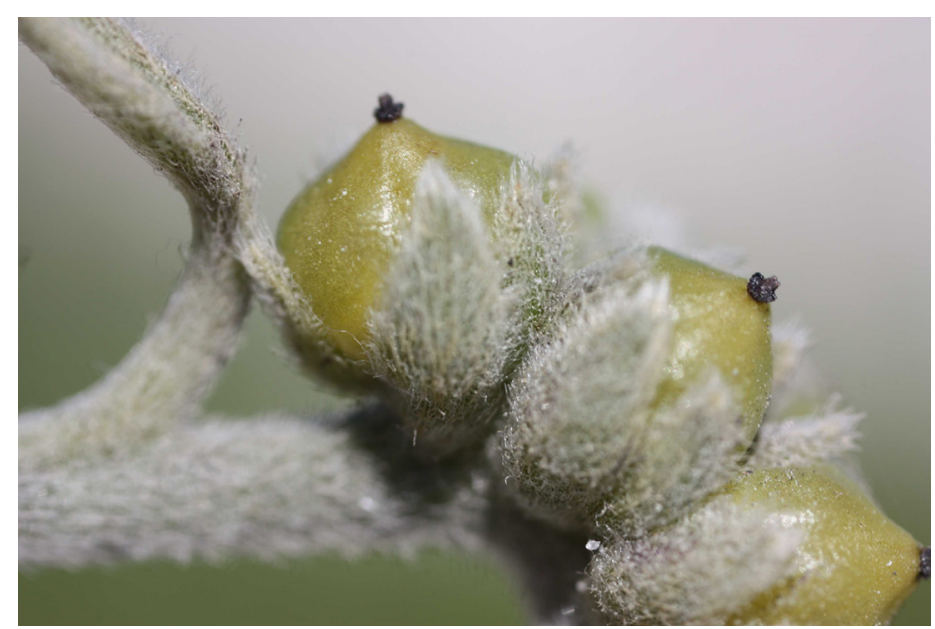

Figure 10. Light gray pubescent stem and calyces with smooth green drupes and persistent styles at the tops.

Credits: Stephen H. Brown, UF/IFAS

\section{Best Ways to Identify Sea Lavender}

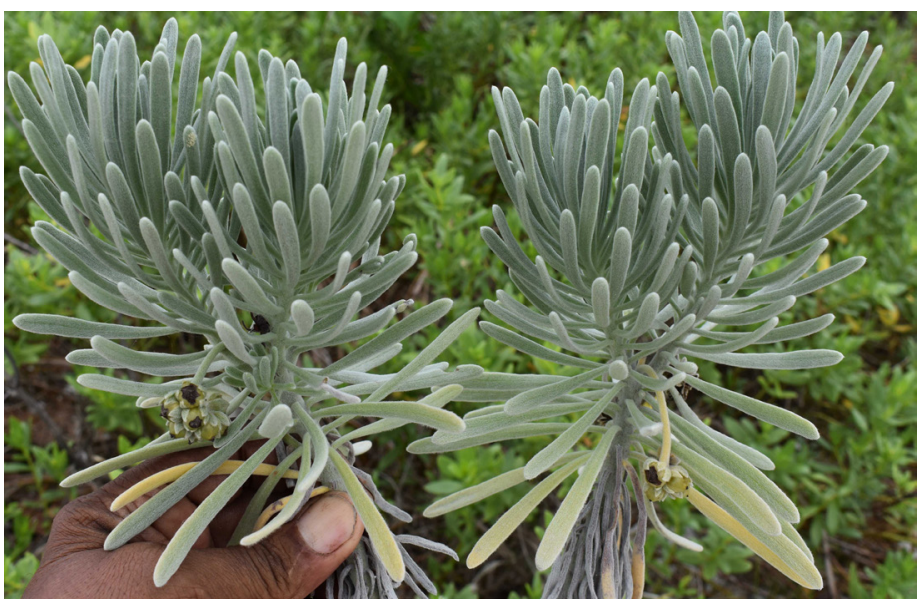

Figure 11. Alternate, spirally arranged, stalkless, linear, pubescent light gray leaves and borne in tufts at stem ends. Clumps of dead foliage hang below.

Credits: Stephen H. Brown, UF/IFAS

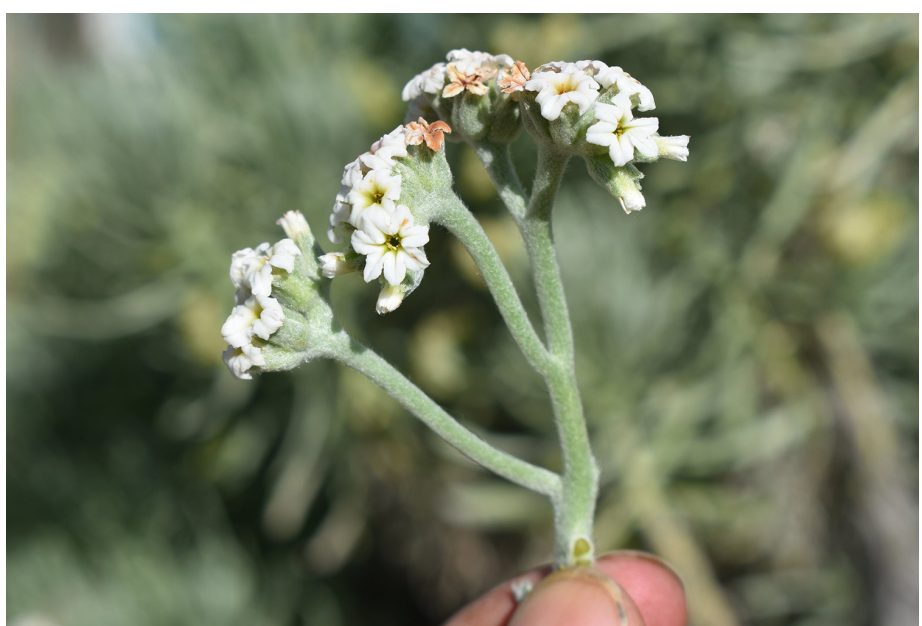

Figure 12. Flowers arranged on helicoid cymes in tight clusters of small, white flowers with greenish-yellow to pinkish throats. Credits: Stephen H. Brown, UF/IFAS

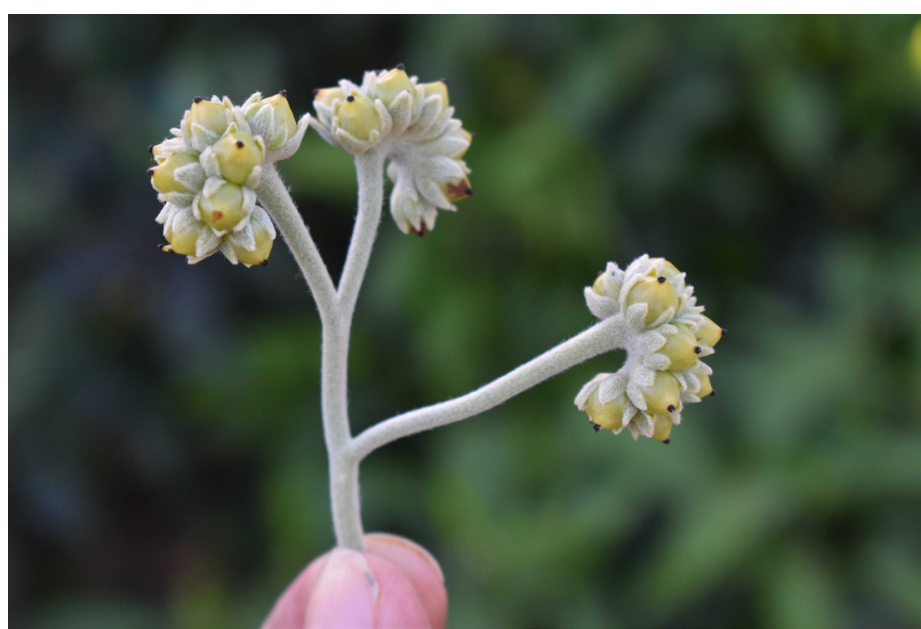

Figure 13. Fruit are ovoid drupes in tightly packed clusters. They have a pointed tip and a persistent black style.

Credits: Stephen H. Brown, UF/IFAS

\section{Propagation}

Sea lavender may be propagated by cuttings, groundlayering, or by seeds. Propagation using stem cuttings is easier and faster. Softwood terminal stem cuttings of about 6 inches long can be started in containers in bright, filtered light and irrigated daily until roots develop. An auxinbased rooting hormone will speed root formation on stem cuttings. For plants intended for dune establishments, place them in small pots with about one inch of stem above the substrate. Roots typically develop within six to eight weeks. Rooted cuttings should be allowed to grow for several months in containers and must be acclimated to full sun before they are ready for beach or landscape planting.

Gardeners can root stem cuttings directly in the ground if the soil is kept consistently moist. Ground layering may be used for small-scale propagation or to develop the size of a colony. Seed germination rates are typically low, and seeds may require scarification to germinate.

This is a Florida endangered plant and it is illegal to obtain plants, seeds, or cuttings from coastal and other natural areas.

\section{Beach and Landscape Uses and Maintenance}

\section{Beach Plants}

Sea lavender is highly tolerant of saline beach soils and salt spray. Plants are used primarily to prevent or slow down erosion on dunes and coastal strands and to foster new communities of an endangered species. Large-flowered coastal plants, such as railroad vine (Ipomoea pes-caprae (L.) R. Br.) and dune sunflower (Helianthus debilis Nutt.), 
are good companion plants for sea lavender. Sea lavender may be used to add texture and color contrast to an area where sea oats (Uniola paniculata L.) planting is mandatory.

Industry reports indicate that adequate beach coverage can be achieved in one or two years by spacing 3-gallon container plants on 3 feet centers. Larger plants typically have a higher survival rate. Experienced planters report that the most important factor in dune planting for beach stabilization is to plant deep. Transplant sea lavender from containers to the dune at a depth of 1 to 2 inches deeper than the top of the roots in the containers, or place half of the aerial part of the plant under the sand. Wind can expose the roots of unestablished, shallowly planted plants, causing them to dehydrate and die. Wet the sand to help hold it in place during excavation. Otherwise, loose sand may fill the planting holes as soon as holes are dug. Water plants whenever possible until they are established. Plants usually begin rooting in the sand at the branch nodes in three or more years after planting.

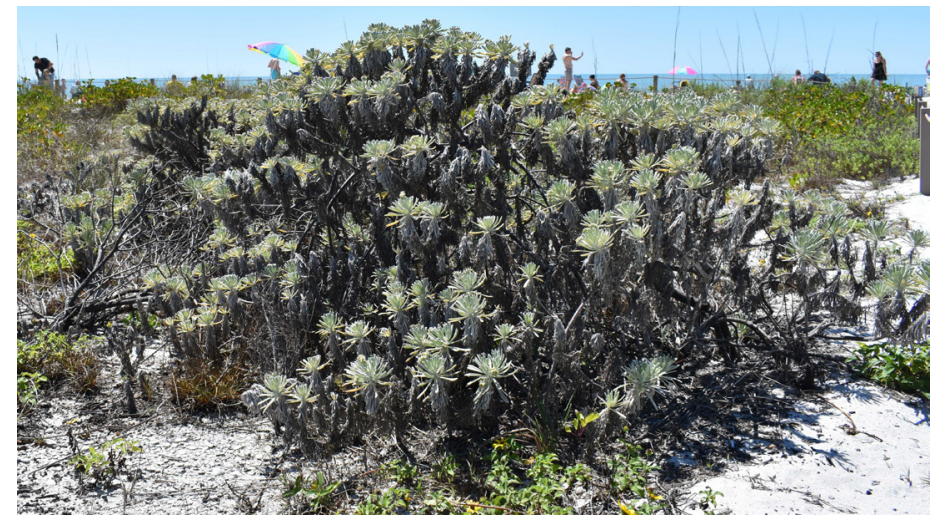

Figure 14. A plant, about three feet tall, used for beach stabilization. Credits: Stephen H. Brown, UF/IFAS

\section{Landscape Plants}

Typically, sea lavender planted in inland landscapes are not as healthy or long-lived as those in dune habitats. However, healthy and vigorous plants can be found growing inland. Overwatering and soils with high organic matter are the principal causes of failure in inland landscapes.

In the landscape, sea lavender can be used as a specimen shrub, a foundation plant, an uneven groundcover, or as an irregular hedge. Sea lavender grows best in full sun but may adapt as an understory plant in dappled light if soil drainage and airflow are excellent. Sea lavender planted in a landscape setting can be smaller (1-gallon containers) than those used for beach restorations because the growing environment is less extreme.

For foundation or groundcovers, space plants four to six feet apart in free-draining soil. Keep the soil slightly moist until established. Once fully established, sea lavender is extremely drought tolerant and rarely requires irrigation. Plants irrigated during the dry winter and spring seasons tend to retain a greater proportion of leaves than nonirrigated plants. This plant has low nutritional needs, so fertilizer application is rarely (if ever) required. Healthy plants respond well to occasional pruning to maintain shape and to remove dead or damaged branches. Large clumps may have bare spots in the canopy as the plants age and continue to spread. This can be remedied by replanting in the exposed area.

Root rot is probably the biggest concern in irrigated landscapes. To help maintain established plants in good condition, reduce or eliminate irrigation in all but the driest weather and avoid over-fertilization.

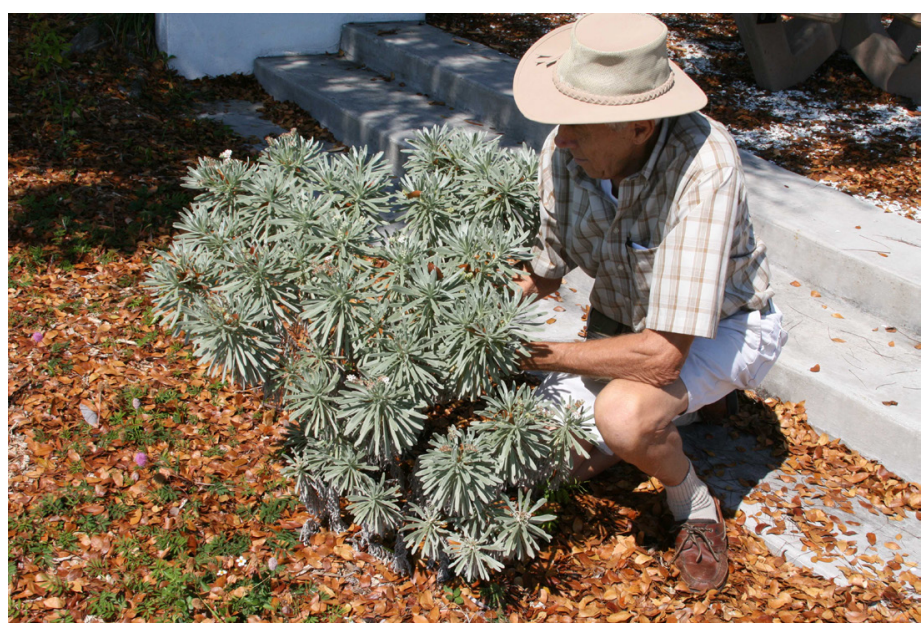

Figure 15. Small landscape plant in April.

Credits: Stephen H. Brown, UF/IFAS

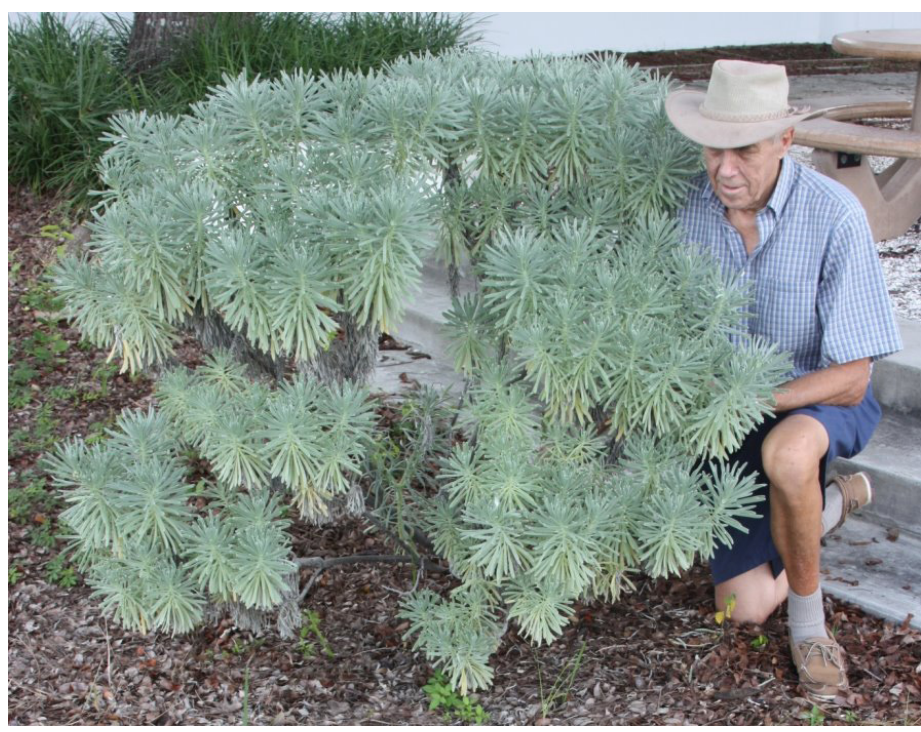

Figure 16. Same plant as in Figure 15 in August of the following year, 16 months later.

Credits: Stephen H. Brown, UF/IFAS 


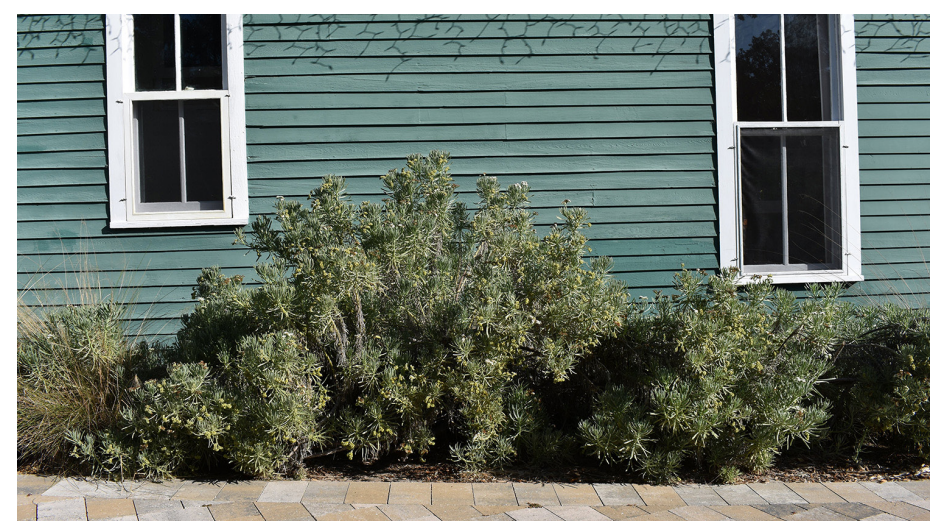

Figure 17. Sea lavender used as a foundation groundcover.

Credits: Stephen H. Brown, UF/IFAS

\section{List of Botanical Terms}

Calyx: (pl. calyces, calyxes): The outermost whorl of the flower, consisting of separate or fused sepals, which enclose and protect the flower bud.

Conical: Cone-shape with the point of attachment at the broad end.

Cyme: A broad, flat-to-rounded inflorescence in which the central, terminal flowers mature before the outer ones.

Drupe: A fleshy fruit that does not split open at maturity, usually with a single seed surrounded by a stony outer part, e.g., avocado, mango, peach.

Entire: Complete, not toothed, notched, or divided, with smooth margins.

Helicoid: Spirally coiled and one-sided.

Inflorescence: The arrangement of a flower cluster on a stem or axis.

Linear: line-like; long and narrow with nearly parallel sides.

Nutlet: A single-seeded component of a fruit that splits away retaining the seed, typical of the Lamiaceae and Boraginaceae.

Obovate: Inverse egg-shaped; broader above the middle and rounded at both ends.

Ovoid: Egg-shaped; broader below the middle, and rounded at both ends.

Pubescent: Covered with dense, short, straight, soft hairs.

Reflexed: Abruptly curved or bent downwards or backwards.
Scarification: Superficially scratching, etching, or burning.

Spatulate: Shaped like a spatula or a spoon, broader and rounded above and gradually tapering to the base.

Stalkless: Lacking a petiole or leaf stalk.

Style: The usually narrow portion of the pistil between the stigma and the ovary; a component of the female reproductive organs in a flower.

Throat: The opening of a fused calyx or corolla.

\section{References}

Broschat, T.K. and A.W. Meerow. 2001. Reference Guide to Florida Landscape Plants. Hollywood, Florida: Betrock Information System, Inc.

Centro de Investigación Científica de Yucatán Herbarium. 2010. "Flora de la Península de Yucatán." http://www.cicy. $\mathrm{mx} /$ sitios/flora digital/ficha_virtual.php? especie $=1089$

Correll, D. S., and H. B. Correll. 1982. Flora of the Bahama Archipelago: including the Turks and Caicos Islands. Vaduz, Leichtenstein: J. Cramer Publishing Co.

Craig, R.M., D.C. Smith, and R.D. Roush. 1981. "Propagation of Two Threatened Coastal Dune Plants having Beautification and Erosion Control Features." Proc. Fla. State Hort. Soc. 94: 202-204.

Davidse, G., M. S. Sousa, S. Knapp, F. Chiang, and C. U. Ulloa. 2012. Flora Mesoamericana. St. Louis: Missouri Botanical Garden Press

Gann, G. D., M. E. Adbo, J. W. Gann, G. D. Gann, Sr., S. W. Woodmansee, K. A. Bradley, E. Grahl and K. N. Hines. 2016. "Sea-lavender, Sea-Rosemary: Heliotroprium gnaphalodes." http://www.regionalconservation.org/beta/ nfyn/plantdetail.asp?tx=Tourgnap

Hall, D. W. and W. J. Weber. 2011. Wildflowers of Florida and the Southeast. China: D.W. Hall and J.H. Byrd.

Howard, R. A. 1989. Flora of the Lesser Antilles: Leeward and Windward Islands, Vol. 6: Dicotyledoneae. Arnold Arboretum, Harvard University.

Morton, J.F. 1990. Trees, Shrubs and Plants for Florida Landscaping: Native and Exotic. Tallahassee, Florida: Florida Department of Agriculture and Consumer Services. 
Nellis, D.W. 1994. Seashore Plants of South Florida and the Caribbean. Sarasota, Florida: Pineapple Press, Inc.

Wunderlin, R. P., B. F. Hansen, A. R. Franck, and F. B. Essig. 2018. "Atlas of Florida Plants." http://florida.plantatlas.usf. edu/Plant.aspx?id=582 